\title{
Supply chain performance and visit interest of restaurants: The role of buzz and viral marketing strategic
}

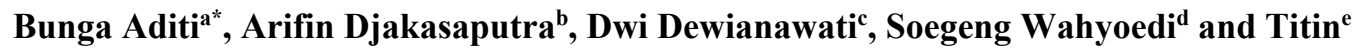

${ }^{a}$ Fakultas Ekonomi Bisnis Universitas Harapan Medan, Indonesia

${ }^{b}$ Universitas Tarumanagara, Indonesia

${ }^{c}$ Department of Management, Mayjend Sungkono University, Indonesia

${ }^{d}$ Faculty of Economics and Business, Krida Wacana Christian University, Indonesia

${ }^{e}$ Fakultas Ekonomi, program studi manajemen, Universitas Islam Lamongan

\section{A B S T R A C T}

\section{Article history:}

Received October 12, 2021

Received in revised format

October 26, 2021

Accepted December 142021

Available online

December 142021

Keywords:

Buzz marketing

Viral marketing

Supply chain performance

Visit interest

Restaurants

\begin{abstract}
The purpose of this study was to analyze the relationship between buzz and viral marketing strategy on supply chain performance and visit interest of restaurants in Banten Indonesia. This type of research used explanatory with a quantitative approach using SEM-based variance analysis, this is because the dependent and independent variables in this study amounted to more than one so that they could use variance-based SEM to summarize the formulation of the analysis. The study was conducted on 120 restaurant owner respondents in the province. Banten Indonesia. The distribution of the questionnaire in this study was carried out in two stages, namely the distribution of online questionnaires via google form to restaurant owner consumers. The sampling technique used in this study is accidental sampling, namely the determination of the sample based on accidental samples. The results of this study are buzz marketing has a significant effect on supply chain performance, buzz marketing has a significant effect on visit interest, viral marketing has a significant effect on supply chain performance, viral marketing has a significant effect on visit interest, visit interest has a significant effect on supply chain performance.
\end{abstract}

\section{Introduction}

In the digital era, the current economy is based on the digital revolution and information management, where the internet network facilitates the interaction of consumers and businesspeople. According to Alwana et al. (2020) the existence of any internet network can be done either just looking for information or running a business. One of the developments of progress in the field of information technology is the emergence of internet media. The United States of America was the first country to use internet media which can access information from all over the world. If the internet network is in the territory of the country. According to Rudyanto et al. (2021a) and Juliana et al. (2021) the internet as a means of communication was initially widely used to send letters to each other by using the features that exist in the internet media, developing to socialize with anyone who can be invited to make friends even, if necessary, from all over the world. Over time, social networking sites emerged. According to Alwana et al. (2020) and Bruzzone et al. (2020) the development of internet-based marketing methods is finally known by a new term, namely viral marketing. According to Napitupulu et al. (2021) and Utama et al. (2021) viral marketing for business people has a very important role, namely with the existence of social media that can provide new views as an effort to market products and services, in marketing efforts using an approach method that is carried out with buzz marketing, namely a positive or negative statement formed from the opinion of consumers, both prospective and former consumers of a product that can be accessed by a wide audience in cyberspace. 
The development of increasingly advanced technology has become an advantage for mankind in carrying out their activities, which initially activities could only be carried out directly, but now because of increasingly advanced technology, human work has become easier. According to Haudi et al. (2021) and Purwanto and Juliana (2021) marketing science also develops along with the development of existing technology. The emergence of digital marketing is none other than motivated by the advancement of technology, marketing strategy is a mindset in marketing that will be used to achieve its marketing goals. According to Hendrayati and Pamungkas (2020), marketing strategy contains specific strategies for the target market, positioning, marketing mix, and the amount of marketing expenditure. One of the digital marketing strategies is buzz marketing. Buzz marketing is capturing the attention of a customer and a media that gets to the point of talking about a brand or talking about a company we own, and it becomes entertaining, interesting, and has news value. According to Bhattacharya et al. (2019), e-commerce is a sales system developed after the invention of the internet. This kind of marketing or sales system can reach the whole world at the same time without having to set up branch offices in all countries. In addition, it can also be done 24 hours without stopping. Through a computer unit connected to the internet, companies can market their products. According to Chidir et al. (2021) and Muhajir et al. (2021) online marketing through social media, such as Instagram, is a form of technological sophistication which is used by the public to upload a photo or image for many people to see. Not only do businesspeople use Instagram, but also consumers mostly use smartphones to just view photos on Instagram social media. An attractive photo display can lead to consumer desire to buy products that have been offered by Instagram. Therefore, Instagram is often used as a medium for implementing Buzz Marketing.

According to Affandi et al. (2020) and Pramono et al. (2021), business or marketing through online media is now widely done by all circles, therefore in doing online marketing companies need a good marketing strategy, namely by using word of mouth marketing strategies to buzz marketing, which later the company must be able to make a consumer believe in the product offered and consumers make purchasing decisions on their products and consumers can recommend these products to other consumers. Making consumers trust and making customers make purchasing decisions on the products offered is not easy, especially when products are marketed using a buzz marketing strategy known as indirect marketing. Purchase decisions are important for marketers to pay attention to because consumers will carry out several processes or stages before making a purchase. Limited information will cause consumers to search for information about a product through various sources, such as family, friends, advertisements, and websites. According to Bhattacharya et al. (2019) and Bestari et al. (2021), personal communication channels in the form of word of mouth (word of mouth) can be an effective promotion method because they are generally delivered from consumers by consumers and to consumers, so that satisfied consumers or customers can become advertising media for companies. In addition, personal word of mouth communication channels do not require large costs because through satisfied customers, referrals or references to the company's products will be more easily spread to other consumers.

One technique to create word of mouth is buzz marketing. Buzz marketing itself is actually not something new in the world of marketing, but the internet provides a new way to implement it. This technique does not cost a lot but has a big impact. Definition of buzz marketing according to Bhattacharya et al. (2019), Bestari et al. (2021), Divya et al. (2021) and Hendrayati and Pamungkas (2020) buzz marketing is to attract the attention of consumers and the media to talk about our brand or company so that it becomes entertainment, more interesting and becomes something that deserves to be made news. The goal is to increase sales which continue to increase from year to year. According to Bestari et al. (2021), Divya et al. (2021) and Hendrayati and Pamungkas (2020) Viral marketing is a marketing technique by utilizing electronic media to achieve a certain marketing goal which is carried out through a communication process that reproduces itself in a chain. The concept of its work which is similar to the proliferation of viruses, namely multiplying yourself, makes this concept called viral marketing. Viral marketing can be in the form of word-of-mouth marketing that is reinforced by marketing activities and the effects of social networks.

The supply chain is a network of interdependent and interconnected organizations that work together to control, regulate and improve the flow of materials and information from suppliers to end users. Supply chain is a system that involves the production, delivery, storage, distribution and sale of products in order to meet the demand for these products. This includes the production process in manufacturing, the transportation system that moves manufactured products to retailer outlets, warehouses where the products are stored, distribution centers where large shipments are divided into small quantities to be sent to stores, and finally to the retailer. According to Yuliantoro et al. (2019) and Prahiawan et al. (2022), supply chain management is an integrative method or approach to manage the flow of products, information and money in an integrated manner involving parties from upstream to downstream consisting of suppliers, factories, distribution networks and logistics services. So basically, supply chain management is an integrated system of managing information, goods, and services from the earliest suppliers to the last consumers. Mehdi (2021), Ravichandran et al. (2020) and Rezvani et al. (2017) revealed that supply chain is a system in which an organization distributes its production goods and services to its customers. This chain is also a network of various organizations that are interconnected and have the same goal, namely as best as possible to organize the procurement of goods, the term supply chain also includes the process of changing these goods, for example from raw goods to finished goods. The supply chain concept is a new concept in looking at logistics problems. Mehdi (2021), Ravichandran et al. (2020) and Rezvani et al. (2017) stated that supply chain management focuses on integrating and managing the flow of goods and services and information through the supply chain to make it responsive to customer needs while lowering total costs. Along with the development of today's market that is growing, customer needs are also getting 
higher. So, it takes the role of suppliers in the management and distribution of products to the final customer. One of the keys to success in any organization is the ability to measure performance.

A product is said to have been consumed if the consumer has decided to visit. According to Rudyanto et al. (2021b) and Wijaya et al. (2021), the decision to visit is influenced by the value of the product being evaluated. If the perceived benefits are greater than the sacrifice to get it, then the urge to buy it is higher. On the other hand, if the benefits are less than the sacrifices, usually the buyer will refuse to buy and will generally switch to evaluating other similar products. Interest in visiting is a psychological force that exists within the individual, which has an impact on carrying out an action. According to Ravichandran et al. (2020) and Rezvani et al. (2017) consumer buying interest is a consumer behavior that has a desire to buy or choose a product, based on experience in choosing, using and consuming or even wanting a product. The purpose of this study was to analyze the relationship between buzz and viral marketing strategic on supply chain performance and visit interest of restaurants in Banten Indonesia.

\section{Hypothesis Development}

\subsection{Relationship between Buzz Marketing and Supply Chain Performance}

Previous studies on the relationship between buzz marketing and supply chain performance by Irwansyah et al. (2019) and Kamran et al. (2021) concluded that buzz marketing has a positive and significant effect on supply chain performance, another study by Mohr (2017) and Mehdi (2021) also concluded that buzz marketing has a positive and significant effect on supply chain performance and this result is in line with Ravichandran et al. (2020) and Rezvani et al. (2017) that buzz marketing has a positive and significant effect on supply chain performance. Based on the results of previous studies, the following hypotheses were formulated:

\section{$\mathbf{H}_{1}$ : Buzz marketing has a positive effect on supply chain performance.}

\subsection{Relationship between Buzz Marketing and Visit Interest}

Previous studies related to the relationship between buzz marketing and Visit Interest conducted by Santoso et al. (2020) and Satrio et al. (2020) stated that buzz marketing has a significant effect on visiting interest. Another study by Sung et al. (2021) and Trivedi et al. (2017) stated that buzz marketing has a significant effect on visiting interest and this result is in line with Yulianto et al. (2018) that buzz marketing has a significant effect on visiting interest. Based on the results of previous studies, the following hypotheses were formulated:

H2: Buzz marketing has a positive effect on visit interest.

\subsection{The relationship between viral marketing and supply chain performance}

Previous studies related to the relationship between viral marketing and supply chain performance by Bhattacharya et al. (2019) indicate that viral marketing has a positive effect on supply chain performance. Also, Bestari et al. (2021) stated that viral marketing has a positive effect on supply chain performance. Other studies by Divya et al. (2021) and Hendrayati and Pamungkas (2020) concluded that it had a positive effect on supply chain performance. Based on the results of previous research, the following hypothesis was formulated:

\section{$\mathbf{H}_{3}$ : Viral Marketing has a positive effect on supply chain performance.}

\subsection{The relationship between viral marketing and visit interest}

Previous research related to the relationship between viral marketing and visit interest was carried out by Irwansyah et al. (2019) and Kamran et al. (2021) who concluded that viral marketing has a positive effect on visit interest, this result is in line with Mohr (2017) and Mehdi (2021) which states that viral marketing has a positive effect on visit interest. Another study by Ravichandran et al. (2020) and Rezvani et al. (2017) also stated that viral marketing had a positive effect on visit interest. Based on the results of previous studies, the following hypothesis was formulated:

\section{$\mathbf{H}_{4}$ : Viral Marketing has a positive effect on visit interest.}

\subsection{Relationship of Visit Interest and supply chain performance}

Previous studies related to the relationship between visit interest and supply chain performance conducted by Bhattacharya et al. (2019) which states that visit interest has a positive and significant effect on supply chain performance, other studies by Bestari et al. (2021) and Divya et al. (2021) concluded that visit interest has a positive and significant effect on supply 
chain performance, this result is in line with Hendrayati and Pamungkas (2020) that visit interest and supply chain performance.

Based on the results of previous studies, the following hypotheses were formulated:

H5: Visit interest has a positive effect on supply chain performance.

\section{Method}

This type of research used explanatory with a quantitative approach using SEM-based variance analysis, this is because the dependent and independent variables in this study amounted to more than one so that they could use variance-based SEM to summarize the formulation of the analysis. The study was conducted on 120 restaurant owner respondents in the province. Indonesian Banten. The distribution of questionnaires in this study was carried out in two stages, namely the distribution of online questionnaires via google form to restaurant owner consumers. The sampling technique used in this study is accidental sampling, namely the determination of the sample based on accidental samples.

\section{Result and Discussion}

The tests carried out in the analysis of variance-based SEM have two stages, namely the outer model and the inner model test. The explanation of the test is as follows:

\section{Test Outer Model}

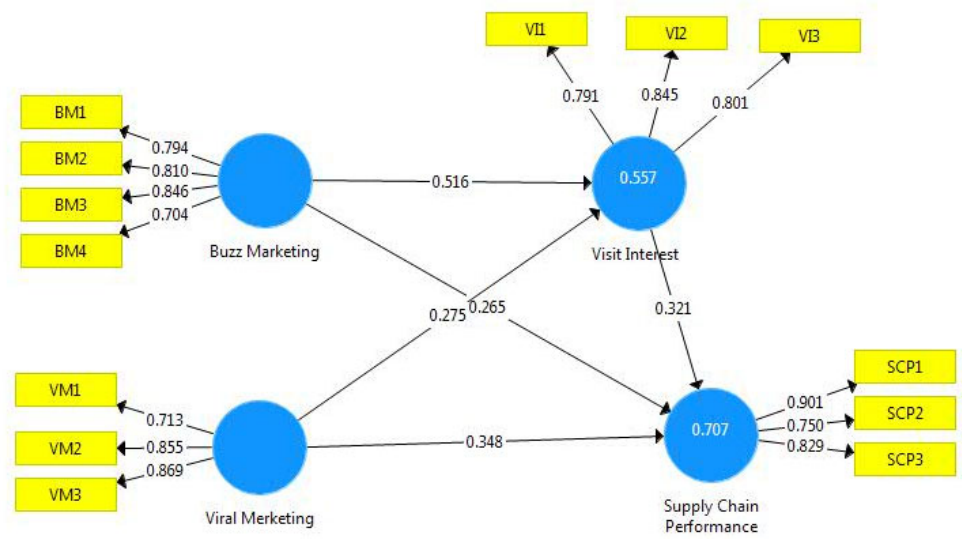

Fig. 1. Validity Testing

The convergent validity test on the outer model aims to determine whether the indicators with latent variables are valid, with a validity value above 0.70 (Purwanto \& Juliana, 2021). Fig. 1 shows that the validity value of each indicator is above 0.7 , so that all indicators research is declared valid. In the outer model test in addition to convergent validity, there is also a validity reliability test, namely a test that aims to determine the reliability of indicators in measuring the variables, while the variable is said to be valid if it has an AVE value above 0.5 and a Cronbach Alpha value above 0.7 (Purwanto \& Juliana, 2020), the following is a discriminant validity test in this study:

Table 1

Average Variance Extracted (AVE)

\begin{tabular}{llll}
\hline Variables & Cronbach's Alpha & Composite Reliability & (AVE) \\
\hline Buzz Marketing & 0.799 & 0.869 & 0.625 \\
Supply Chain Performance & 0.77 & 0.867 & 0.687 \\
Viral Marketing & 0.745 & 0.855 & 0.665 \\
Visit Interest & 0.748 & 0.854 & 0.661 \\
\hline
\end{tabular}

Table 1 shows that all Cronbach alpha and average variance extracted values exceed the minimum limit so that all variables are declared valid.

\section{Inner model test}

The inner model test contains an explanation of the R-Square, while the R-square value in this study is as follows: 
Table 2

R Square

\begin{tabular}{lll}
\hline Dependent Variables & R Square & R Square Adjusted \\
\hline Supply Chain Performance & 0.707 & 0.698 \\
Visit Interest & 0.557 & 0.548 \\
\hline
\end{tabular}

From the R-Square table, it can be concluded that $55.70 \%$ of visit interest is influenced by buzz and Viral Marketing, while the remaining $44.30 \%$ is influenced by other variables outside the study. Variable supply chain performance Influenced by the variable buzz, viral marketing, and interest in visiting by $70.7 \%$ while the remaining 29.3 is influenced by other factors outside the theme of this study. In addition to reliability in the inner model test, there is also a hypothesis test, while the hypothesis test in this study is as follows:

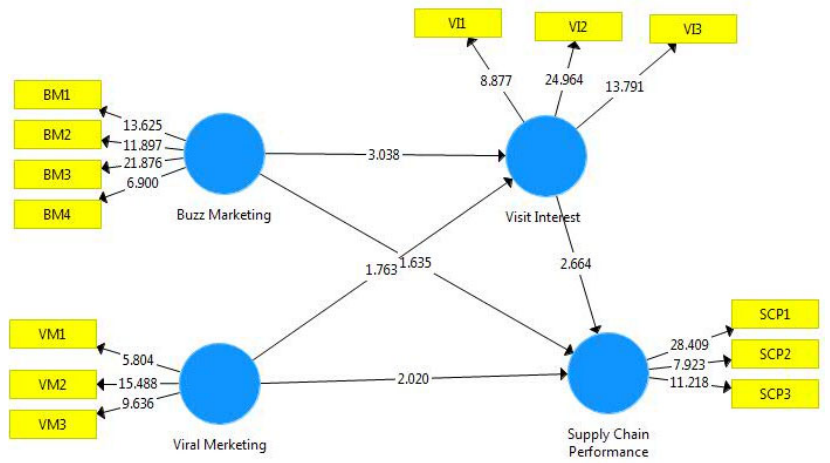

Fig. 2. Hypotheses Testing

Table 3

Hypotheses Testing

\begin{tabular}{|c|c|c|c|}
\hline Correlation & Original Sample $(\mathrm{O})$ & T Statistics & P Values \\
\hline Buzz Marketing $\rightarrow$ Supply Chain Performance & 0.265 & 1.595 & 0.048 \\
\hline Buzz Marketing $\rightarrow$ Visit Interest & 0.516 & 3.214 & 0.001 \\
\hline Viral Marketing $\rightarrow$ Supply Chain Performance & 0.348 & 2.038 & 0.042 \\
\hline Viral Marketing $\rightarrow$ Visit Interest & 0.275 & 1.822 & 0.049 \\
\hline Visit Interest $\rightarrow$ Supply Chain Performance & 0.321 & 2.673 & 0.008 \\
\hline
\end{tabular}

From the value of the hypothesis testing table, it is known that all hypotheses in the study are accepted because they have a p-value below 0.05

\section{Buzz Marketing has a significant effect on Supply Chain Performance.}

The hypothesis which states that Buzz Marketing has a significant effect on Supply Chain Performance is accepted when the level of significance is five percent. Buzz Marketing is formed from consumer statements or perceptions and impressions where statements from consumers can provide a stimulus to other consumers. The better the statements and consumer perceptions about a product or service can make an impetus to make visitors. In this study, consumers revealed that they were interested in cafes based on suggestions from friends, and other reviewers from mass media such as Instagram, Twitter and Facebook. The results of this study are supported by research conducted by Irwansyah et al. (2019), Kamran et al. (2021), Mohr (2017), Mehdi (2021), Ravichandran et al. (2020) and Rezvani et al. (2017).

\section{Buzz Marketing has a significant effect on Visit Interest}

The hypothesis which states that Buzz Marketing has a significant effect on visiting interest is accepted. This can be proven by the results of the $t$ test where the value of sig. 0.0001 is smaller than the standard significance of 0.05 which indicates a positive and significant result. Buzz Marketing can be said as a marketing technique to spread messages using social networks which can be a strategy to provide stimulus to consumers because through modern viral marketing consumers can find out information about a desired product. So, curiosity will arise and the urge to decide to visit the desired place. Respondents' perceptions obtained through the questionnaire show that they are more interested in cafes that tend to become trends and are widely used as content in cyberspace. This study has similar results with research conducted by Santoso et al. (2020), Satrio et al. (2020), Sung et al. (2021), Trivedi et al. (2017) and Yulianto et al. (2018). 
3. Viral Marketing has a significant effect on Supply Chain Performance

The hypothesis which states that Viral Marketing has a significant effect on Supply Chain Performance is accepted. This can be proven by the results of the t test where the value of sig. 0.042 is smaller than the standard significance of 0.05 which indicates a positive and significant result. These significant positive results indicate that the greater the number of people and the mass media who discuss, discuss, or recommend outdoor cafes, the higher the number of consumers who decide to visit, the results of this study are supported by research by Bhattacharya et al. (2019), Bestari et al. (2021), Divya et al. (2021) and Hendrayati and Pamungkas (2020).

\section{Viral Marketing has a significant effect on Visit Interest}

The hypothesis which states that Viral Marketing has a significant effect on Visit Interest is accepted. This is because the results of the $t$ test where the value of sig. 0.049 is less than the standard significance of 0.05 , which indicates a significant result. Significant positive results between viral marketing and the decision to visit because consumers need to see and seek advice to decide to visit an outdoor cafe. Because for them virality is not enough to make a visit, and consumers are still considering other possible values such as service, advice from friends, trust in cafes and so on. The results of this study are in line with research by Irwansyah et al. (2019), Kamran et al. (2021), Mohr (2017), Mehdi (2021), Ravichandran et al. (2020) and Rezvani et al. (2017).

\section{Visit Interest has a significant effect on Supply Chain Performance}

The hypothesis which states that Visit Interest has a significant effect on Supply Chain Performance is accepted. This can be proven by the results of the $t$ test where the value of sig. 0.008 is smaller than the standard significance of 0.05 , which indicates a positive and significant result. This significant positive result means that if consumers have an interest in visiting the cafe, most will decide to visit. The results of this study have similarities with the research conducted by Bhattacharya et al. (2019), Bestari et al. (2021), Divya et al. (2021) and Hendrayati and Pamungkas (2020).

\section{Practical implications}

To improve restaurant supply chain performance, management needs to strengthen buzz marketing and viral marketing, significantly increasing buzz and viral marketing will encourage an increase in restaurant supply chain performance, therefore restaurant management must improve and maintain indicators that support buzz and viral marketing variables. Improving the supply chain performance of restaurants is very important in the era of the industrial revolution 4.0 because if restaurants cannot compete, they will not be able to survive. To increase visit interest, restaurants need to strengthen buzz marketing and viral marketing, a significant increase in buzz and viral marketing will encourage an increase in restaurant visit interest, therefore restaurant management must improve and maintain indicators that support buzz and viral marketing variables. Increasing restaurant visit interest is very important in the era of the industrial revolution 4.0 because if restaurants cannot compete, they will not be able to survive.

\section{Theoretical implications}

Buzz marketing has a significant effect on supply chain performance. The results of this study are supported by research conducted by Irwansyah et al. (2019) and Kamran et al. (2021) and they are also supported by Mohr (2017) and Mehdi (2021) that Buzz marketing has a significant effect on supply chain performance. Other studies by Ravichandran et al. (2020) and Rezvani et al. (2017) also produced the same result, namely Buzz marketing has a significant effect on supply chain performance. Buzz Marketing has a significant effect on visiting interest. This study has similar results with research conducted by Santoso et al. (2020) and Satrio et al. (2020) which states that Buzz Marketing has a significant effect on visiting interest. The result is also in line with Sung et al. (2021) and Trivedi et al. (2017) that buzz marketing has a significant effect on visiting interest. Another study by Yulianto et al. (2018) also stated that buzz marketing has a significant effect on visiting interests. Viral marketing has a significant effect on supply chain performance, the results of this study are supported by research by Bhattacharya et al. (2019) that Viral Marketing has a significant effect on supply chain performance. The results of this study are in line with Bestari et al. (2021) and Divya et al. (2021) that Viral Marketing has a significant effect on Supply Chain performance. Another study by Hendrayati and Pamungkas (2020) also stated that Viral Marketing has a significant effect on supply chain performance.

Viral Marketing has a significant effect on Visit Interest. The results of this study are in line with research by Irwansyah et al. (2019) and Kamran et al. (2021) that Viral Marketing has a significant effect on Visit Interest, the result is in line with Mohr (2017) and Mehdi (2021) that Viral Marketing has a significant effect on Visit Interest. Studies by Ravichandran et al. (2020) and Rezvani et al. (2017) also produced the same result, namely Viral Marketing has a significant effect on Visit Interest. Visit Interest has a significant effect on Supply Chain Performance. The results of this study have similarities with the research conducted by Bhattacharya et al. (2019) and Bestari et al. (2021) that Visit Interest has a significant effect on supply chain performance. This result is in line with research by Divya et al. (2021) that Visit Interest has a significant effect 
on Supply Chain Performance and is supported by Hendrayati and Pamungkas (2020) which states that Visit Interest has a significant effect on supply chain performance.

\section{Conclusion and future studies}

According to the results of this study, Buzz Marketing has a significant effect on Supply Chain Performance, Buzz Marketing has a significant effect on Visit Interest, Viral Marketing has a significant effect on Supply Chain Performance, Viral Marketing has a significant effect on Visit Interest, Visit Interest has a significant effect on Supply Chain Performance. This is still possible to be developed in retesting the research model by adding new variables, such as Brand Trust and other situational factors. Future research is expected to be able to develop the conceptual and modeling of this study on the objects of a broader research study by sticking to the internet marketing scheme but in other industrial fields. Thus, a comparison can be obtained regarding the results of internet marketing efforts for long-term needs. For further researchers, in order to expand the scope of research related to Modern Viral Marketing and Electronic word of mouth, for example, based on a number of similar retail companies that implement the same implementation. To improve supply chain performance and restaurant visit interest, restaurants need to strengthen buzz marketing and viral marketing, a significant increase in buzz and viral marketing will encourage an increase in restaurant supply chain performance and restaurant visit interest. Therefore, restaurant management must improve and maintain supporting indicators. buzz and viral marketing variables. Improving the supply chain performance of restaurants is very important in the era of the industrial revolution 4.0 because if restaurants cannot compete, they will not be able to survive.

\section{Research limitations}

This research was conducted in Banten Province, the results of which may not necessarily be applicable in other provinces. The sample in this study was only 120 restaurant owners in Banten Province, the results of which could not necessarily be generalized to other restaurant owners. Data analysis using structural equation modeling (SEM) using SmartPLS 3.0 software, the results may be different when using other statistical software. The use of the google form questionnaire is only followed by respondents who have smartphones even though many respondents do not use smartphones.

\section{References}

Affandi, A., Sarwani, A. S., Erlangga, H., Siagian, A. O., Purwanto, A., Effendy, A. A., \& Juhaeri, G. (2020). Optimization of MSMEs Empowerment in Facing Competition in the Global Market during the COVID-19 Pandemic Time. Systematic Reviews in Pharmacy, 11(11), 1506-1515.

Alwana, H. J. (2020). Buzz Marketing and its Role in Achieving Market Share. Methodology, 12(7).

Bruzzone, A. G., Agresta, M., \& Hsu, J. H. (2020). Word of Mouth, Viral Marketing and Open Data: A Large-Scale Simulation for Predicting Opinion Diffusion on Ethical Food Consumption. International Journal of Food Engineering, 16(5-6).

Bhattacharya, S., Gaurav, K., \& Ghosh, S. (2019). Viral marketing on social networks: An epidemiological perspective. Physica A: Statistical Mechanics and its Applications, 525, 478-490.

Bestari, D. K. P., Saudi, M. H., Sinaga, O., \& Setyadi, A. (2021). The influence of Experiential Marketing, Guerrilla Marketing and Buzz Marketing in the formation of Consumer Purchase Intention in the JD. ID Marketplace. Review of International Geographical Education Online, 11(6), 382-397.

Chidir, G., Novitasari, D., Iskandar, J., Hutagalung, D., Pramono, T., Maulana, Safitri, K., Fahlevi, M., Sulistyo, A.B., \& Purwanto, A. (2021). The role of customer e-trust, customer e-service quality and customer e-satisfaction on customer eloyalty. International Journal of Data and Network Science, 6(2), 1-8.

Divya, T., \& Evanita, S. (2021). The influence of social media and celebrity endorsers on culinary purchase intention by viral marketing as a mediating variable. Operations Management and Information System Studies, 1(1), 41-50.

Haudi, H., Rahadjengb, E. R., Santamoko, R., Putrac, R. S., Purwoko, D., Nurjannahe, D., \& Purwanto, A. (2021). The Role of E-Marketing and E-Crm on E-Loyalty of Indonesian Companies During Covid Pandemic and Digital Era. Uncertain Supply Chain Management, 10, 2022

Hendrayati, H., \& Pamungkas, P. (2020). Viral marketing and e-word of mouth communication in social media marketing. In 3rd Global Conference On Business, Management, and Entrepreneurship (GCBME 2018) (pp. 41-48). Atlantis Press.

Irwansyah, M. R., Devi, S., \& Dewi, L. G. K. (2019, November). The Influence of Viral Marketing on Online Purchasing Decisions of Students. In International Conference on Tourism, Economics, Accounting, Management, and Social Science (TEAMS 19) (pp. 111-116). Atlantis Press.

Juliana, J., Parani, R., Irene, N., Sitorus, B., Pramono, R., \& Maleachi, S. (2021). Study of Community Based Tourism in the District West Java. International Journal of Sustainable Development and Planning, 16(2), 277-285.

Kamran, H., Mahmood, M., \& Badawi, S. (2021). Exploring a Broadband Marketing Strategy to Build Customers' Relationship Management: Buzz Marketing Perspective. A Case Study of Virgin Broadband in Stafford-Shire University. In The Big Data-Driven Digital Economy: Artificial and Computational Intelligence (pp. 415-425). Springer, Cham. 
Muhajir, Mukaromah, H., Fathudina, Purwanti, K.L, Ansoria, Y., Fahlevi, M., Rosmayati, S., Tanjung, R., Budiarti, R.H.S., Rosyadi \& Purwanto, A.(2021). The role of buzz and viral marketing strategic on purchase intention and supply chain performance. Uncertain Supply Chain Management,10(2).1-8

Mohr, I. (2017). Managing buzz marketing in the digital age. Journal of Marketing Development and Competitiveness, 11(2), $10-16$.

Napitupulu, J., Pramono, R., \& Saragih, E. L. L. (2021). Determinants of Tourist Attraction of the Heritage Tourism. Journal of Environmental Management \& Tourism, 12(2), 507-514.

Mehdi, S. (2021). A comparative method of viral and neural marketing, with a modern marketing approach. Turkish Journal of Computer and Mathematics Education (TURCOMAT), 12(14), 132-138.

Purwanto, A., \& Juliana (2021). The effect of supplier performance and transformational supply chain leadership style onsupply chain performance in manufacturing companies. Uncertain Supply Chain Management, 10(2), 1-8

Prahiawan, W., Fahlevi, M., Juliana, J., Purba, J., Khamaludind, K., Syam, S., \& Lestari, S. (2022). The effect of supply chain quality perception and country of origin on Smartphones purchase intention of Indonesian consumers. Uncertain Supply Chain Management, 10(1), 277-284.

Pramono, R., Sondakh, L. W., Bernarto, I., Juliana, J., \& Purwanto, A. (2021). Determinants of the small and medium enterprises progress: A case study of SME entrepreneurs in Manado, Indonesia. The Journal of Asian Finance, Economics, and Business, 8(1), 881-889.

Ravichandran, M., \& Karthika, K. R. (2020). A study on impact of viral marketing on consumer's purchasing decisions with reference to college students, tiruchirappalli district.

Rudyanto, R., Pramono, R., Juliana, J. (2021a). Perception of Knowledge of the Risk of the COVID -19 Pandemic Regarding Touring Intentions and Tourism Travel Recommendations. Journal of Environmental Management and Tourism, (Volume XII,Summer), 4(52), 929 - 947. DOI:10.14505/jemt.v12.4(52).08

Rudyanto, R., Pramono, R., \& Purwanto, A. (2021b). The influence of antecedents of supply chain integration on company performance. Bagchi, PK \& Chun HB (2005). Supply Chain Integration: a European survey. The International Journal of Logistics Management, 16(2), 275-294.

Rezvani, M., Ghahramani, S., \& Haddadi, R. (2017). Network marketing strategies in sale and marketing products based on advanced technology in micro-enterprises. International Journal of Trade, Economics and Finance, 8(1), 32-37.

Santoso, S., Hurriyati, R., \& Sultan, M. A. (2020). Effect of viral marketing on changes in consumer behavior and decision in using smartphone. In Advances in Business, Management and Entrepreneurship (pp. 298-302). CRC Press.

Satrio, D., Priyanto, S. H., \& Nugraha, A. K. (2020). The effects of positive and negative emotion on viral marketing effectiveness. In Emerging Trends in Psychology, Law, Communication Studies, Culture, Religion, and Literature in the Global Digital Revolution (pp. 9-13). Routledge.

Sung, E. C. (2021). The effects of augmented reality mobile app advertising: Viral marketing via shared social experience. Journal of Business Research, 122, 75-87.

Trivedi, J. (2017). The effect of viral marketing messages on consumer behavior. Journal of Management Research, 17(2), 84-98.

Utama, I. G. B. R., Laba, I. N., Junaedi, I., Krismawintari, N. P. D., Turker, S. B., \& Juliana, J. (2021). Exploring Key Indicators of Community Involvement in Ecotourism Management. UTAMA, I Gusti Bagus Rai et al. Exploring Key Indicators of Community Involvement in Ecotourism Management. Journal of Environmental Management and Tourism, $12,808-817$

Wijaya, O., Sulistiyani, S., Pudjowati, J., Kurniasi, N., \& Purwanto, A. (2021). The role of social media marketing,entertainment, customization, trendiness, interaction and word-of-mouth on purchase intention: An empirical study fromIndonesian smartphone consumers. International Journal of Data and Network Science, 5(3), 231-238.

Yulianto, M. R., Suhartono, S., \& Ronny, R. (2018). The Effect of Viral Marketing on Blackberry Messenger Applications on Customer Satisfaction Through Purchasing Decisions on University Students in Sidoarjo. JBMP (Jurnal Bisnis, Manajemen dan Perbankan), 4(2), 122-135.

Yuliantoro, N., Goeltom, V., Juliana, I. B., Pramono, R., \& Purwanto, A. (2019). Repurchase intention and word of mouth factors in the millennial generation against various brands of Boba drinks during the Covid 19 pandemic. African Journal of Hospitality, Tourism and Leisure, 8(2), 1-11.

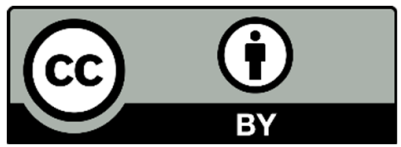

(C) 2022 by the authors; licensee Growing Science, Canada. This is an open access article distributed under the terms and conditions of the Creative Commons Attribution (CC-BY) license (http://creativecommons.org/licenses/by/4.0/). 